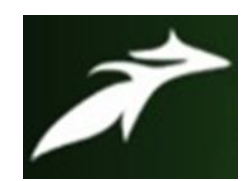

Ramakant Singh Sidar, International Journal of Advances in Agricultural Science and Technology,

Vol.4 Issue.2, February- 2017, pg. 19-32

ISSN: 2348-1358

Impact Factor: 6.057

\title{
Weed Management in Mustard (Brassica juncea L. Czern \& Coss.): A Review
}

\author{
Ramakant Singh Sidar \\ RMD College of Agriculture and Research Station, Indira Gandhi Krishi Vishwavidyalaya \\ Ambikapur, Surguja-497001 (Chhattisgargh) \\ DOI: 10.47856/ijaast.2017.v04i2.001
}

\begin{abstract}
Indian mustard (Brassica juncea) is an important winter (rabi) season oil seed crop. It is also known as Rai or Laha. In India it'is believed to be an introduction from China. It has been grown for oilseed, greens and as a spice. Mustard greens are an excellent source of vitamin A, vitamin B6, vitamin $\mathrm{C}$, vitamin $\mathrm{E}$ and beta-carotene. It basically consists of folic, oleic, erucic and linoleic acids. The oil content varies from 37-49 per cent depending upon the type and variety of the crop. India is one of the leading oilseeds producing countries ranking third after United States of America and China with 21 per cent of world's area and 15 per cent of world's production. Oilseeds form the second largest agricultural commodity after cereals, sharing 13 per cent of the country's gross cropped area and accounts for nearly 5 per cent of gross national product (Reddy and Pati, 1998). In India, it occupies an area of 5,44, 500 hectares (Annual Report 2004) with production of 2,85,800 tormes (Annual Report 2003) accounting for 33 per cent of total output of oilseeds (Singh and Singh, 1998). In Himachal Pradesh, it covers an area of 8.9 thousand hectares with a production of 3.24 million tormes (Annual Report 2004). Among various components of production technology, weed control in Indian mustard needs due attention. As this crop is grown in poor soils with poor management practices, weed infestation is one of the major causes of low productivity (Singh and Singh, 1998).

The weeds depending upon the type, density and duration of competition accounts for 2370 per cent reduction in yield of gobhi sarson (Tiwari 1998). Competition by weeds at initial stages is a major limiting factor to its productivity. However, during later stages the crop grows vigorously and has suppressing effect on weeds. Weeds are largely taken care manually. But manual weeding is tedious, cumbersome and labour intensive besides being costly. Therefore,
\end{abstract}




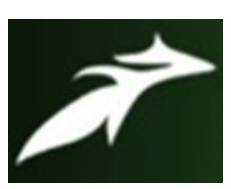

Ramakant Singh Sidar, International Journal of Advances in Agricultural Science and Technology,

Vol.4 Issue.2, February- 2017, pg. 19-32

ISSN: 2348-1358

Impact Factor: 6.057

chemical weed control is the only alternative for effective control. The most common herbicidal weed control measure recommend in Indian mustard is the pre-emergence application of pendimethalin. But it does not control all grassy weeds. Farmers and extension functionaries require information on post emergence herbicidal weed control due to one or the other reason, if pre-emergence application of the herbicide was not made. Under situations when weeds are not taken care completely by pre-emergence application of herbicides, post-emergence herbicides may have an added economic advantage over super imposition of hand weeding. Therefore, it is imperative to find out an alternative weed management strategy for achieving season long weed control in Indian mustard. Keeping above points in mind, the present study entitled, Identification of different weeds on mustard crop with special reference to herbicides in Northern Hills zone of Chhattisgarh

Keywords: Weeds, mustard, herbicides and chhattisgarh

\section{Introduction:}

Indian mustard [Brassica juncea (L.) Czern \& Cross] is one of the oil seed crop of the state of Madhya Pradesh. The problem of low productivity continues to be a major issue for agricultural planners and researchers. The best way to increase the productivity of mustard is by improving crops. Weeds are regarded as one of the major negative factors of crop produce loss due to competition for nutrient, moisture, light and space which have been reported as high as 30-70\% (Tiwari,1998). Mustard crop is grown both in subtropical and temperate countries. India occupies the third position with regard to average production of rapeseed and mustard in the world. It is raised to 5.77 million hectares with an annual production of 6.59 million tonnes and average productivity of $1142 \mathrm{~kg} / \mathrm{ha}$ in the country. In Madhya Pradesh rapeseed and mustard is grown in 791 thousand hectares area with annual production of 849 thousand tonnes and average productivity of $1075 \mathrm{~kg} / \mathrm{ha}$. But in Gwalior district it covers an area of 58.5 thousand hectares with annual production 75.9 thousand tonnes and average productivity of $1303 \mathrm{~kg} / \mathrm{ha}$ (CLRS M.P., 2009-10). The mustard crop is infested with grassy as well as broadleaf weeds. Weeds substantially reduce the productivity and production of mustard due to competition for various inputs. A wide ranging yield reduction in the crop on account of weeds is well documented. Therefore, there is a need to create an environment that is detrimental to weeds and favourable to crop. In India, mustard weeds are recognized as one of the major negative factors of crop production. Broomrape (Orobanche aegyptica pers.), a holoparasitic weed has been causing heavy losses to the mustard crop in light soils of Grid region. Weed infestation during early stages reflected the crop growth and reduction in yield up to 58 percent (Prusty et al., 1996). At later stages, shading caused by plant height and broad dorsoventral leaves help in suppressing weed growth (Chakaiyar and Ambasht, 1990). Many workers have stated that glyphosate at lower rates $(82 \mathrm{~g} / \mathrm{ha})$ 30DAS provided excellent control of broomrape without any toxic effect on 


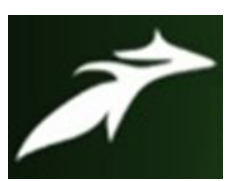

Ramakant Singh Sidar, International Journal of Advances in Agricultural Science and Technology,

Vol.4 Issue.2, February- 2017, pg. 19-32

ISSN: 2348-1358

Impact Factor: 6.057

mustard crop, but it caused some toxicity at higher rates $(123 \mathrm{~g} / \mathrm{ha})$ 60DAS to the crop. Other herbicides like fluchloralin and pendimethalin did not control this weed (Kumar, 2002).

\section{Weed Management:}

A brief review related to research work done on the "Weed management in mustard (Brassica juncea L. Czern \& Coss.)" is presented in this chapter. An attempt has been made to cite at many references as possible related to weed control measures on population and dry weight of weeds and various parameters of mustard.

Palled (1979) reported that fluchloralin as pre-plant incorporation was an effective herbicide for controlling Orobanche. Palled et al. (1985) studied on chemical weed control in tobacco and found that fluchloralin at $2 \mathrm{~kg} / \mathrm{ha}$ gave significantly higher cured leaf yield than hoeing and was equal to weed free condition. Fluchloralin at the rate of $3.0 \mathrm{~kg} / \mathrm{ha}$ was highly effective against Orobanche spp. Nemli et al. (1989) reported that glyphosate at $40 \mathrm{~g} / \mathrm{ha}$ gave $73 \%$ control of $O$. ramose in tobacco but caused a yield reduction. Early application of glyphosate at low rate $(5 \mathrm{~g} / \mathrm{ha})$ provided $50 \%$ O. ramosa control with slightly increased yields. Krishnamurthy and Chari (1991) applied oils to young, unflowered broomrape shoots at 1-5 drops/shoot with a dropper. All the oils killed the parasitic shoots effectively, their optimum dosages being 1 drop/shoot for Eucalyptus, Pongamia, soybean and tobacco seed oils and 2 drops for rice bran oil. One drop of Eucalyptus and Pongamia oil, two drop of tobacco seed oil, 3 drops soybean oil and 4drops rice bran oil were taken to kill the buds of broomrape. Phytotoxicity on tobacco leaves was observed only with Eucalyptus oil. Americanos and Vouzounis (1995) studied on the control of Orobanche in cabbage and found that the parasite weed was effectively controlled in the field by spraying glyphosate at 60-100 g a.i./ha twicely. Further, they also reported that trifluralin @ $0.9 \mathrm{~kg}$ a.i./ha may have a beneficial effect in reducing Orobanche infestation, while incorporation of organic matter into the soil did not produce any beneficial effect. Kaneria and Patel (1995) revealed that weed free condition and two hand weeding were very effective in improving (relative to weedy controls) growth attributes such as plant height and primary and secondary branches/plant at harvest, yield components such as the siliqua/plant and seed weight/plant, seed and stover yields, harvest index and the uptake of nitrogen by Indian mustard. Dhanapal G.N. (1996) assessed the efficacy of 15 herbicides for control of broomrape and results indicated that $0.5 \mathrm{~kg} / \mathrm{ha}$ glyphosate 60 DAS and $0.01 \mathrm{~kg}$ imazaquin 30 DAS gave best weed reduction (75-80\%) and increased the yield of tobacco by $43 \%$. Dhanapal et al. (1998a) assessed the effect of natural oils on the control of broomrape in a naturally infested tobacco field.Natural oils which were less expensive and biodegradable differed in their ability to kill young broomrape spikes. Neem, coconut, sunflower, castor, niger and mustard oils killed the buds of orobanche within 3 to 5 days without phytotoxicity to tobacco. He further reported that glyphosate at $500 \mathrm{~g}$ ai/ha applied at $60 \mathrm{DAS}$ and imazaquin at $10 \mathrm{~g}$ ai/ha applied at $30 \mathrm{DAS}$ 


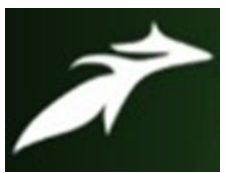

Ramakant Singh Sidar, International Journal of Advances in Agricultural Science and Technology,

Vol.4 Issue.2, February- 2017, pg. 19-32

ISSN: 2348-1358

Impact Factor: 6.057

reduced the number of above-ground broomrape spikes by 75 to $80 \%$, respectively, and increased tobacco yield by 80 to $>100 \%$ compared to the untreated plots. Imazethapyr and EPTC were found to be less effective for broomrape control, but they still led to substantially higher tobacco yields. Dhanapal et al. (1998b), Singh and Singh (1998) indicated that pre-plant incorporation of fluchloralin at $1.5 \mathrm{~kg}$ a.i./ha significantly reduced the density and biomass of weeds (Cyperus rotundus, Convolvulus arvensis and Anagallis arvensis) by 38.6 in first year and 46.1 per cent in second year, compared to unweeded control. Length of primary root, nodules/plant and dry weight of root were also enhanced significantly by fluchloralin application at $1.5 \mathrm{~kg}$ a.i./ha. Yadav et al. (1999a) reported that the use of pendimethalin as pre-emergence and fluchloralin as pre-planting caused significant reduction in weed population and weed dry matter resulting increased yield and its attributes and net return per hectare and per rupee investment. He further found that weed control treatments like pendimethalin $1.0 \mathrm{~kg}$ a.i./ha as pre-emergence, fluchloralin $1.0 \mathrm{~kg}$ a.i./ha pre-plant incorporation, hand weeding at $25 \mathrm{DAS}$ and hand weeding at 20 and 40 DAS decreased weed population and weed dry weight and consequently increased the number of leaves per plant, plant height, number of siliquae per plant, seed weight per plant and seed yield of mustard over that of weedy check. Yadav et al. (1999b), Singh et al. (2000) observed that stale seedbed integrated with pre-plant fluchloralin $1.0 \mathrm{~kg} / \mathrm{ha}$ achieved excellent control of all major weeds and recorded the highest seed yield (1682 $\mathrm{kg} / \mathrm{ha})$ with highest net return(Rs. 12694/ha). Pendimethalin was found only slightly phytotoxic at 1.0 $\mathrm{kg} / \mathrm{ha}$. Fluchloralin $1.0 \mathrm{~kg} / \mathrm{ha}$, pendimethalin 0.75 and $1.0 \mathrm{~kg} / \mathrm{ha}$ and hand weeding twice at 4 and 7 weeks after sowing significantly decreased the weed dry weight and increased the plant height, primary branches per plant, number of siliquae per plant, seeds/siliqua, test weight and seed yield compared to weedy check. Mishra and Kurchania (2001) registered that herbicide application reduced the biomass of Cichorium intybus, Medicago hispida, P. minor, Chenopodium album and V. sativa, but failed to control Cyperus rotundus, Anagallis arvensis and Convolvulus arvensis. Hand weeding was most effective in controlling weed dry matter accumulation, followed by oxadiazon. However, $1.0 \mathrm{~kg}$ isoproturon/ha gave the highest seed yield, net return, and benefit:cost ratio. Mishra and Sharma (2001) revealed that in unweeded plot, sedge population decreased and broad leaved weed population was increased with advancement of cropping season, however, grass population did not show any definite trend. Pre-emergence application of alachlor with one matter throughout the crop season which was 73.5 and $73.8 \%$ less dense and 85.0 and 81.7\% less heavy compared to unweeded control in 1996-97 and 199798, respectively, and recorded seed yield at par with weed-free. Sharma et al. (2001) noted that all the weed control treatments significantly reduced weed density at 60 DAS. However lowest weed density and dry matter were recorded with application of oxflurofen during both years. Sharma et al. (2001) further observed that pendimethalin $0.75 \mathrm{~kg} / \mathrm{ha}$ was found superior to fluchloralin $1.0 \mathrm{~kg} / \mathrm{ha}$ in reducing weed dry weight and improving seed yield of wheat but at par 


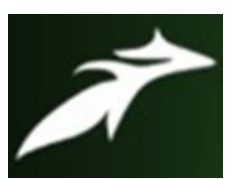

Ramakant Singh Sidar, International Journal of Advances in Agricultural Science and Technology,

Vol.4 Issue.2, February- 2017, pg. 19-32

ISSN: 2348-1358

Impact Factor: 6.057

with hand weeding at 30 DAS (Sharma et al. 2001), Singh et al. (2001) reported that weed management practices decreased the weed population and dry weight and consequently increased the weed control efficiency; yield attributes (number of siliquae per plant, seed/siliqua and also seed weight per plant), seed yield and mean net return over weedy check. The highest seed yield was recorded in weed free, followed by 2 manual weedings at 25 and 45 DAS which was found more effective in controlling the weeds compared with other treatments. Among the herbicides, pre-emergence application of pendimethalin $1.0 \mathrm{~kg}$ a.i./ha recorded higher seed yield and found best substitute of repeated manual weeding where the labour costs were too high. Anand and Vaishya (2002) showed that fluchloralin at $1000 \mathrm{~g} / \mathrm{ha}$ and clodinafop at $50 \mathrm{~g} / \mathrm{ha}$ produced lower weed density than the rest of the treatments. Fluchloralin at $1000 \mathrm{~g} / \mathrm{ha}$ reduced weed density by $52 \%$ and weed dry weight by $48 \%$ compared to the weedy control. All weed control treatments decreased weed $\mathrm{N}$ uptake. Fluchloralin at $1000 \mathrm{~g} / \mathrm{ha}$ and clodinafop at $50 \mathrm{~g} / \mathrm{ha}$ resulted in the lowest weed $\mathrm{N}$ uptake. The highest seed yield was obtained in the weed free control followed by fluchloralin at $1000 \mathrm{~g} / \mathrm{ha}$ and clodinafop at $50 \mathrm{~g} / \mathrm{ha}$. Covarelli (2002) reported that glyphosate (180-324 ml/ha) caused a 100 per cent reduction in broomrape but it significantly depressed tobacco yield. Kumar (2002) found that glyphosate at low rates (82 g/ha) provided excellent control of broomrape without any toxic effect on mustard crop but it caused some toxicity at higher rates $(123 \mathrm{~g} / \mathrm{ha})$ to the crop. Other herbicides like fluchloralin, trifluralin and pendimethalin did not control this weed. Kurchania et al. (2002) it was reported by that isoproturon $1.0 \mathrm{~kg} / \mathrm{ha}$ reduced the population of major weeds, namely Phalaris minor, Medicago hispida, Melilotus alba, and Chenopodium album but not scarlet pimpernel (Anagallis arvensis). Om Prakash (2002) further stated that hand weeding at 20 and 40 DAS, and pre-emergence application fluchloralin at 0.75 and $1.0 \mathrm{~kg} / \mathrm{ha}$ applied during were most effective in the reduction of weed density and dry matter, and in the improvement of seed yield and yield components (number of primary branches and siliquae per plant, and 1000-grain weight) of mustard. Sharma and Jain (2002) indicated that herbicide application and hand weeding significantly reduced weed dry matter. The highest yield, plant height, number of branches per plant, number of seeds per siliqua, number of siliquae per plant, and 1000-seed weight were recorded in weed-free plots, followed by hand weeding at 30 and 45 DAS. Among the herbicides, the pre-emergence application of $1.0 \mathrm{~kg}$ isoproturon/ha exhibited the highest weed control efficiency. The preemergence application of $0.75 \mathrm{~kg}$ isoproturon/ha was most effective in increasing yield, net returns, cost benefit ratio, and yield attributes except plant height and number of siliquae per plant. Herbicides at higher rates were found phytotoxic. Singh and Sinsinwar (2002) observed that all the weed control treatment significantly reduced weed dry weight. Hand weeding at 25 and $50 \mathrm{DAS}$, and $0.5 \mathrm{~kg}$ isoproturon a.i./ha at pre-emergence were most effective in the reduction of weed dry matter production. In Indian mustard, the tallest plants with the highest number of primary branches were obtained under the weed-free plotsfollowed by hand weeding 


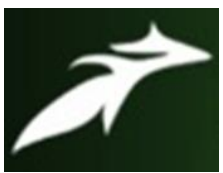

Ramakant Singh Sidar, International Journal of Advances in Agricultural Science and Technology,

Vol.4 Issue.2, February- 2017, pg. 19-32

ISSN: 2348-1358

Impact Factor: 6.057

at 25 and 50 DAS, $0.5 \mathrm{~kg}$ isoproturon a.i./ha at pre-emergence+hand weeding at $25 \mathrm{DAS}$, and 1.5 $\mathrm{kg}$ isoproturon a.i./ha at pre-emergence. The highest grain yield was observed in weed-free plots followed by hand weeding at 25 and 50 DAS or $1.5 \mathrm{~kg}$ isoproturon a.i./ha at pre-emergence. The seed yield increased with the increase in the rate of isoproturon applied at pre-emergence. The highest oil yield was recorded in weed-free plots, followed by hand weeding at 25 and 50 DAS and $1.5 \mathrm{~kg}$ isoproturon a.i./ha at pre-emergence. Report (2003) revealed that 2 drops of soybean oils per young shoot of Orobanche was the most potent killer of the weed which recorded significantly higher seed yield of mustard (1452 kg/ha). Buttar and Aulakh (2003) reported that all weed treatments reduced the weed dry matter compared to unweeded plots. The weed dry matter was lowest in trifluralin + once hoeing $(16.4 \mathrm{~g} / \mathrm{m} 2)$, followed by $1.00 \mathrm{~kg}$ trifluralin/ha $(17.4 \mathrm{~g} / \mathrm{m} 2)$. These treatments recorded the highest weed control efficiency 86.5 and $85.6 \%$, respectively. Weed dry matter was highest in the weedy control $(123.4 \mathrm{~g} / \mathrm{m} 2)$, followed by 0.75 $\mathrm{kg}$ isoproturon/ha at $2 \mathrm{DAS}(2.82 \mathrm{~g} / \mathrm{m} 2)$. Among all treatments, the weedy control recorded the lowest 1000-grain weight. The 1000-grain weight was highest in trifluralin + once hoeing, followed by $1.00 \mathrm{~kg}$ trifluralin/ha. The mean grain yield was highest with trifluralin + once hoeing $(2274 \mathrm{~kg} / \mathrm{ha})$, followed by $1.00 \mathrm{~kg}$ trifluralin/ha $(2259 \mathrm{~kg} / \mathrm{ha})$, weed-free control $(2215$ $\mathrm{kg} / \mathrm{ha}$ ) and $0.75 \mathrm{~kg}$ trifluralin/ha $(2159 \mathrm{~kg} / \mathrm{ha})$ treatments. The grain yield was lowest in the weedy control (1562 kg/ha). Kataria et al. (2003) observed that weed dry weight decreased with increasing rates of trifluralin, fluchloralin and pendimethalin. The average seed yield decreased with increasing rates of fluchloralin but increased with increasing rates of trifluralin and pendimethalin which resulted to higher increments in seed yield compared to fluchloralin. Power et al. (2003) reported highest weed control efficiency with two hand weeding. Sharma and Singh (2003) reported that weed management practices significantly increased the yield attributes (number of siliquae per plant, number of seeds per siliqua, siliqua length, seed weight per plant and 1000-seed weight) and yield of Indian mustard over the control. Weed management practices increased the seed yield of Indian mustard by $54-80 \%$ over the weedy control (11.42 quintal/ha). Weed management practices did not exert significant influenced on oil content in seed. Preemergence application of pendimethalin @ $1.0 \mathrm{~kg}$ a.i./ha produced significantly higher seed yield of mustard which was at par with pendimethalin @ $1.5 \mathrm{~kg}$ a.i./ha (P.E.). The direct spray of glyphosate@1.0\% produced minimum seed yield due to its phytotoxic effect, but recorded maximum Orobanche control efficiency followed by two drops of soybean oil per young shoot of Orobanche (Annual Report, 2004). Bazaya et al. (2004) observed significant reductions in weed population and dry matter with fluchloralin supplemented with hand weedings at 30 and 60 DAS, which was at par with isoproturon and pendimethalin supplemented with hand weedings at 30 and 60 DAS. Polythene mulch and weed-free treatments recorded the highest values for branches per plant, siliquae per plant, seeds per siliqua, 1000-seed weight and seed yield. Fluchloralin alone or in combination with hand weeding recorded the highest values of these 


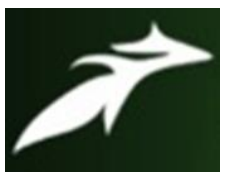

Ramakant Singh Sidar, International Journal of Advances in Agricultural Science and Technology,

Vol.4 Issue.2, February- 2017, pg. 19-32

ISSN: 2348-1358

Impact Factor: 6.057

growth and yield parameters among the herbicide treatments. Fluchloralin alone or in combination with hand weeding at 30 DAS and pendimethalin in combination with hand weeding at 30 DAS recorded the highest benefit: cost ratio. Yadav (2004) revealed that the highest seed yield (17.08 q/ha) was recorded with application of isoproturon+hand weeding at 25 DAS followed by application of metribuzin+hand weeding at 25 DAS. This treatment also had the highest net return of Rs 16 743/ha and benefit: cost ratio of 4:1 over other treatments. Unchecked weeds caused $37.5 \%$ seed yield loss with the minimum net return (Rs 9312/ha) and benefit:cost ratio (3.02:1). Chauhan et al. (2005) registered that the application of oxyfluorfen at $0.25 \mathrm{~kg} / \mathrm{ha}$ as pre-emergence, fluchloralin at $1.0 \mathrm{~kg} / \mathrm{ha}$ as pre-plant application and 2 hand weedings at 25 and 40 DAS drastically reduced weed density, weed biomass and increased seed yield. The 2 hand weedings were next to weed-free in giving higher seed yield (17.55 and 17.59 q/ha during 1998 and 1999 respectively), followed by oxyfluorfen at $0.25 \mathrm{~kg} / \mathrm{ha}$ as preemergence in both years. However, oxyfluorfen at $0.25 \mathrm{~kg} / \mathrm{ha}$ was at par with fluchloralin at 1.0 $\mathrm{kg} / \mathrm{ha}$ as pre-plant application and pendimethalin at $0.75 \mathrm{~kg} / \mathrm{ha}$ as pre-emergence. Nepalia (2005) noted that pre-emergence application of oxadiazon was superior in increasing the growth and yield of mustard. Hand weeding, oxyfluorfen and pendimethalin also gave satisfactory results. Rathi et al. (2005) showed that pre-emergence application of pendimethalin at $0.5 \mathrm{~kg} / \mathrm{ha}$ supplemented with one hand weeding at 30 DAS was as effective as hand weeding twice at 20 and 45 DAS in reducing the weed population and dry matter as well as in increasing seed yield (8.65 q/ha) and net return (Rs. 11764.0) over the control. However, hand weeding twice gave maximum additional yield (9.21 q/ha) and net return (Rs. 11836.0) over the weedy control. Sharma et al. (2005) it was reported by that the weed control treatments viz., weed free, hand weeding at $25 \mathrm{DAS}$, hand weeding at 25 and $45 \mathrm{DAS}$, pendimethalin and trifluralin at $0.75 \mathrm{~kg}$ and $1.00 \mathrm{~kg}$ a.i./ha and pendimethalin or trifluralin + one hand weeding at 45 DAS effectively reduced dry weight of weeds at harvest by 71.2-100\% compared with the control. The highest seed yield (1891 kg/ha) was obtained under weed free treatment followed by pre-plant incorporation of trifluralin at $0.75 \mathrm{~kg}$ a.i./ha with one hand weeding $45 \mathrm{DAS}$ and were at par with 2 hand weedings at 25 and 45 DAS. Among different herbicides, pre-plant incorporation of trifluralin at $0.75 \mathrm{~kg}$ a.i./ha was most effective in improving the growth and yield attributes viz., number of branches per plant, number of siliquae per plant and test weight with maximum seed yield and oil yield. Sinha et al. (2005) observed that one hand weeding at 25 DAS gave the highest secondary branches, crop growth rate, leaf area index, 1000-seed weight and seed yield while fluchloralin gave the highest siliqua per plant. One hand weeding at 25 DAS gave the lowest weed count, weed dry weight and weed growth rate, and the highest weed control efficiency. Tekale et al. (2005) showed that all the weed management treatment significantly decreased the dry matter production of weeds the unweeded control. The weed-free condition through timely manual weeding was most effective treatment in improving the growth and yield 


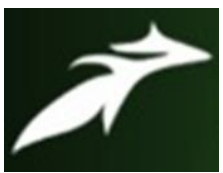

Ramakant Singh Sidar, International Journal of Advances in Agricultural Science and Technology,

Vol.4 Issue.2, February- 2017, pg. 19-32

ISSN: 2348-1358

Impact Factor: 6.057

attributes with the highest seed yield. It was followed by PPI application of fluchloralin at 0.6 $\mathrm{kg} / \mathrm{ha}+$ one hand weeding+IC at 40 DAS. Yadav and Poonia (2005) studied that the herbicidal treatment (fluchloralin at $1.0 \mathrm{~kg} / \mathrm{ha}$ in mustard and $2,4-\mathrm{D}$ at $0.5 \mathrm{~kg} / \mathrm{ha}$ in wheat) in mustardwheat-wheat-mustard rotation reduced the Asphodelus tenuifolius density and total weed density, and enhanced the seed yield of mustard. The use of fluchloralin alone did not control $A$. tenuifolius effectively and, thus, reduced the seed yield of mustard. Bazzaj et al. (2006) showed that pre-emergence applications of Ronstar effectively decreased the weed number as well as weed biomass and increased the weed control efficiency. The tallest plant, total dry matter production and partitioning into leaf, stem and reproductive organs and all other yield contributing attributes were also high in Ronstar-used plots. Setoff also decreased the weed dry weight but at the same time it decreased the plant stand and yield attributes that caused 58\% yield reduction compared to the unweeded control. This indicates that Setoff is detrimental to weeds as well as mustard. Cost benefit analysis revealed that pre-emergence application of Ronstar recorded the highest gross margin and benefit cost ratio than all other the treatments. Hand weeding had the second highest gross margin but its benefit cost ratio was identical to the unweeded control treatments. Rana (2006) observed that pre-emergence application of pendimethalin@ $1 \mathrm{~kg} / \mathrm{ha}$ or 1 hand weeding at 20 days after sowing effectively controlled the weeds and demonstrated a significant increase in seed yield of component crops, system seed yield and net returns over weedy check. Among the weed control treatments, 1 hand weeding at 20 days after sowing proved better in all respect than the pendimethalin and gave 18.6 and $8.3 \%$ higher seed yield of component crops. Sole Indian mustard recorded higher weed control efficiency and suppressed weed count by $12.2 \%$ and weed dry mass by $29.4 \%$ over the sole African mustard. Contrary to this, African mustard gave significantly higher seed yield (2.51 tonnes/ha) and net returns (Rs18 020/ha) that were 9.6 and 13.9\% higher than the sole Indian mustard. Sarkar and Mukherjee (2006) indicated that pendimethalin had higher weed control efficiency than fluchloralin. However, pendimethalin became phytotoxic to mustard and nonselective in action at all the doses tested. Among the herbicides, fluchloralin at $1.25 \mathrm{~kg}$ a.i. ha-1 registered the highest seed yield of mustard (10.39 q ha-1) as it controlled the weeds effectively. However, black necrotic symptom at the base of the plant was observed during siliqua development stage, which disappeared at later part of crop growth. Weeds removed huge amount of plant nutrients from the soil to the tune of $165.13 \mathrm{~kg} \mathrm{~N}, 22.54 \mathrm{~kg} \mathrm{P}$ and $158.84 \mathrm{~kg} \mathrm{~K} \mathrm{ha-1.}$ Fluchloralin at $1.00 \mathrm{~kg}$ a.i. ha-1 was effective as pre-emergence herbicide in mustard to control weeds and to conserve the plant nutrients in soil on account of $118.08 \mathrm{~kg} \mathrm{~N}, 15.56 \mathrm{~kg} \mathrm{P}$ and $104.58 \mathrm{~kg} \mathrm{~K}$ ha-1. Singh (2009) found that the application of isoproturon (post-emergence) at $750 \mathrm{~g} / \mathrm{ha}$, trifluralin (pre-emergence) at $1200 \mathrm{~g} / \mathrm{ha}$, pendimethalin (post-emergence) at $750 \mathrm{~g} / \mathrm{ha}$ and pendimethalin (pre-emergence) at $750 \mathrm{~g} / \mathrm{ha}$ proved most effective in controlling weeds. Weed control efficiency ranged between 50.2 to $84.6 \%$ with different herbicide treatments. 


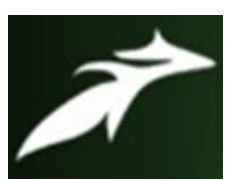

Ramakant Singh Sidar, International Journal of Advances in Agricultural Science and Technology,

Vol.4 Issue.2, February- 2017, pg. 19-32

ISSN: 2348-1358

Impact Factor: 6.057

Among different weed control measures, isoproturon (post-emergence) resulted in the highest weed control efficiency (84.6\%) followed by trifluralin (pre-emergence), pendimethalin (postemergence) and pendimethalin (pre-emergence) at $750 \mathrm{~g} / \mathrm{ha}$. Maximum seed yield (9.92 q/ha) was obtained with the application of trifluralin (pre-emergence) at $1200 \mathrm{~g} / \mathrm{ha}$ which was $83.4 \%$ higher than weedy check, but it was at par with two hand weedings, pendimethalin (preemergence) at $750 \mathrm{~g} / \mathrm{ha}$ and isoproturon (post-emergence) at $750 \mathrm{~g} / \mathrm{ha}$. Singh et al. (2009) reported that weed management practices were superior to unweeded control for yield traits. Highest values of all yield attributes were recorded with weed free treatments closely followed by isoproturon pre-emergence $(1 \mathrm{~kg}$ a.i./ha)+interculture once at 30 DAS except in respect of seed yield/plant, where it was statistically at par to each other. Amongst all weed management treatments, weed free plots gave maximum seed yield (14.73 q/ha). However, with integrated weed management strategy isoproturon pre-emergence $(1 \mathrm{~kg}$ a.i./ha)+interculture once at 30 DAS produced significantly higher seed (14.03 q/ha) and stover yield (46.93 q/ha). Bijanzadeh et al. (2010) observed that herbicides reduced weed biomass compared with the weedy check. At 16 WAP (weeks after planting), application of trifluralin plus propaquizafop plus isoxaben at $1200+200+250 \mathrm{~g}$ a.i./ha and trifluralin plus haloxyfop-p methyl plus isoxaben at 1200+100+500 $\mathrm{g}$ a.i./ha provided best control $(80 \%)$ of wild mustard compared to other treatments. The most effective herbicide treatments were trifluralin plus propaquizafop plus isoxaben and trifluralin plus haloxyfop-p methyl plus isoxaben regardless of the dose applied and provided maximum reduction in total weed biomass (77-89\%) compared to other treatments. Results of both years showed that all herbicide treatments increased oilseed rape grain yield as compared with the weedy check but percentage of oil was not affected by various herbicide treatments. Maximum grain yield was obtained with trifluralin plus haloxyfop-p methyl plus isoxaben at 1200+100+500 g a.i./ha.], Meena and Sah (2011) found that all herbicides resulted in significantly reduced density and dry matter of weeds in Indian mustard. Weed control also reduced nutrient losses caused due to heavy weed infestation. Pre emergence application of oxadiazon $0.50 \mathrm{~kg} / \mathrm{ha}$, pendimethalin $0.75 \mathrm{~kg} / \mathrm{ha}$ and pre-plant incorporation of fluchloralin 0.75 $\mathrm{kg} / \mathrm{ha}$ increased seed yield by $67.3,49.8$ and $36.9 \%$ respectively over the weedy check. Mitra (2011) revealed that pendimethalin at $0.30 \mathrm{~kg}$ a.i./ha was found to be more effective as compared to fluchloralin at $0.70 \mathrm{~kg}$ a.i./ha as reflected by weed dry matter production and yield. Maximum yield (11.3 q/ha) was achieved with the application of pendimethalin at $0.30 \mathrm{~kg}$ a.i./ha as preemergence spray followed by one hand weeding at 35 DAS. The highest gross return (Rs 19,210.00/ha), net income (Rs 8.840.00/ha) and benefit-cost ratio (1.85) were also obtained with application of pendimethalin at $0.30 \mathrm{~kg}$ a.i./ha along with one hand weeding at $35 \mathrm{DAS}$. 


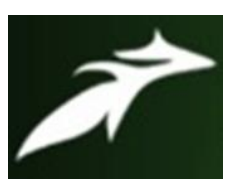

Ramakant Singh Sidar, International Journal of Advances in Agricultural Science and Technology,

Vol.4 Issue.2, February- 2017, pg. 19-32

ISSN: 2348-1358

Impact Factor: 6.057

\section{Conclusion:}

The literature reviewed in this paper highlighted the Identification of different weeds on mustard crop Knowledge of weeds between yield, seed yield and its components is very useful for efficient selection of desirable herbicides.

\section{References:}

[1]. Annual Report (2003). Annual Progress Report of AICRP on Rapeseed Mustard (ICAR). National Research Centre on Rapeseed-Mustard Sewar, Bharatpur (Rajasthan) India. pp. A8.

[2]. Annual Report (2004). Annual Progress Report of AICRP on Rapeseed Mustard (ICAR). National Research Centre on Rapeseed-Mustard Sewar, Bharatpur (Rajasthan) India. pp. A26.

[3]. Americanos, P.G. and Vouzounis, N.A. (1995). Control of orobanche in cabbage. Tech. Bull. Cyperus Agril. Res. Inst. 7(170): 64-70.

[4]. Anand, K.B. and Vaishya, R.D. (2002). Effect of weed control measures on weeds, nitrogen uptake by weeds and yield of mustard. Indian J. Weed Sci. 34(3/4): 305-306.

[5]. Annual Report (2003). Annual Progress Report of AICRP on Rapeseed Mustard (ICAR). National Research Centre on Rapeseed-Mustard Sewar, Bharatpur (Rajasthan) India. pp. A8.

[6]. Annual Report (2004). Annual Progress Report of AICRP on Rapeseed Mustard (ICAR). National Research Centre on Rapeseed-Mustard Sewar, Bharatpur (Rajasthan) India. pp. A26.

[7]. Blackman V.H. (1919). The compound interest law and plant growth. Annals of Botany 33; 353-360.

[8]. Bazaya, B.R., Kachroo, D. and Jat, R.K. (2004). Integrated weed management in mustard (Brassica juncea L.). Indian J. Weed Sci. 36(3/4): 290-292.

[9]. Bazzaj, M. M. Islam, F. Razzaque, M. A. Mahmud, A. A. and Uddin, M. J. (2006).Relative efficacy of chemical weed control on growth, yield and economics in mustard. International Journal of Sustainable Agricultural Technology; 2: (2), 9-15. 6.

[10].Bijanzadeh, E. Ghadiri, H. and Behpouri, A. (2010). Effect of trifluralin, pronamide, haloxyfop-p methyl, propaquizafop, and isoxaben on weed control and oilseed rape yield in Iran. Crop Protection; 29: (8), 808-812. 17.

[11].Biplab Mitra(2011). On farm trial on evaluation of cost-effective weed control measures in rapeseed-mustard under teesta flood plains of Bengal. Environment and Ecology;. 29558.

[12].Banga R.S. and Yadav, A. (2001). Evaluation of herbicides against complex weed flora in Indian mustard. Haryana Journal of Agronomy : 17:48-51.

[13].Bhan V.M. (1992). Weed management a factor for sustainability in crop production In: Proceeding of XII National Symposium on Resource Management for Sustained Crop Production, held At Rajasthan Agriculture University, Bikaner, 209-2016. 


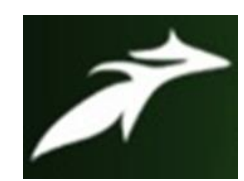

Ramakant Singh Sidar, International Journal of Advances in Agricultural Science and Technology,

Vol.4 Issue.2, February- 2017, pg. 19-32

ISSN: 2348-1358

Impact Factor: 6.057

[14].Kurchania, S.P., Rathi, G.S. Bhalla, C.S. and Mathew, R. (2002). Direct and residual effects of herbicides for weed control in soybean-mustard cropping system. Research Journal. 36(1/2): 13-16.

[15].Meena, M.L. and Dinesh Sah (2011). Effect of weed control and fertilization on yield attributes and seed yield of mustard (Brassic juncea L.) under western plains of UP. Environment and Ecology;. 29: (2A), 929-931. 5.

[16].Mishra, J.S. and Kurchania, S.P. (2001) Weed dynamics, nutrient uptake and yield in Indian mustard (Brassica juncea)-weed ecosystem as influenced by nitrogen levels, planting geometry and herbicides. Indian J. Weed Sci. 46(2): 296-303.

[17].Mishra, P.J. and Sharma, S.N. (2001). Weed dynamics and dry matter production in mustard as influenced by fertility levels and weed management practices. Indian J. Weed Sci. 33(3/4): 151-155.

[18].Mukherjee Dhiman and Singh R.P. (2003). Effect of integrated weed management in Indian mustard cuttivars (Brassica juncea) Haryana. J. Agron. 19(1): 8-10.

[19].Punia, S.S., Malik, R.K., Parvender, Sheoran and Sharma, S.D. (2003). Weed management studies in mustard (Brassica juncea (L.) Haryana J. Agron. 19 (1): 108-109.

[20].Rana, D.S. (2006). Effect of planting patterns and weed management on weed suppression, productivity and economics of African mustard (Brassica carinata) and Indian mustard (Brassica juncea) intercropping. Indian Journal of Agricultural Sciences; 76: (2), 98-102. 6.

[21].Reddy, A.R. and Patil A.P.K. (1998). Effect of different herbicides in controlling weed in yellow sarson. Abstract of papers presented $a^{\wedge}{ }^{\wedge}$ nual Conference of Indian Society of Weed Science, Jodhpur, 86 p.

[22].Sharma, R.P. and Singh, P. (2007). Effect of weed management and phosphorus levels on yield and quality of Indian mustard (Brassica juncea). Annals of Agri. Res. 24 (3): 605609.

[23].Singh SS. (1992). Effect of fertilizer application and weed control on the yield of mustard (Brassica juncea). Indian Journal of Agronomy.; 37:196-198.

[24].Singh, B.D. and Singh, B.P. (1998). Effect of weed management practices and phosphorus levels on weed infestation, nodulation and yield of chickpea + mustard intercropping system. Indian J. Weed Sci. 30 (3/4): 124-128.

[25].Singh, Samunder, R.K., Malik, Balyan, R.S. (1990). Weed management studies in Raya (Brassicajuncea L.) Haryana J. Agron. 8 (1): 16-18.

[26].Singh.; Harphool., Singh, B.P. and Prasad, Hanuman. (2001). Weed management in Brassica species. Indian J. Agron. 46 (3): 533-537.

[27]. Tiwari (1998). Weeds are regarded as one of the major negative factor of crop produce loss due to competitions for nutrients, moisture, light and space which have been reported as high as 30-70\%. Indian j. weed sci. 30: 149-152.

[28]. Tiwari J.P. and Kurchania, S.P. (1993). Chemical control of weeds in Indian mustard (Brassica juncea L.). Indian Agricultural Sciences; 63:272-275.

[29]. Yadav, R.P. 2010. Effect of herbicides alone and in combination with cultural method dn weed cohtrol in Indian mustard (Brassica juncea). Indian Journal of Agronomy 49: 268270. 


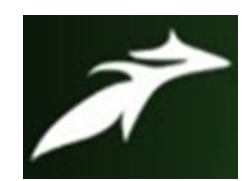

Ramakant Singh Sidar, International Journal of Advances in Agricultural Science and Technology,

Vol.4 Issue.2, February- 2017, pg. 19-32

ISSN: 2348-1358

Impact Factor: 6.057

[30].Yadav, R.P., Shrivastava, V .K. and Dwivedi, S.C. (1999). Comparative efficiency of herbicide in controlling Asphodelus tenuifolius and other weed in Indian mustard (Brassica juncea). Indian J. Agron. 44 (1): 151-155.

[31].Buttar, G.S. and Aulakh, C.S. (2003). Integrated weed management in Indian mustard (Brassica juncea). Indian J. Weed Sci. 35 (3/4): 285-286.

[32].Chakaiyar, S.N. and Ambasht, R.S. (1990). Weeding and weed free duration effects on growth and yield of mustard (Brassica juncea Hook \& Thom.). Acta Bot. Ind. 18: 34-37.

[33].Chauhan, Y.S., Bhargava, M.K. and Jain, V.K. (2005). Weed management in Indian mustard (Brassica juncea). Indian J. Agron. 50 (2): 149-151.

[34].C.L.R.S. (2006). Published by Commissioner Land Record and Settlement, Madhya Pradesh, Gwalior.

[35].Covarelli, L. (2002). Studies on the control of broomrape (Orobanche ramosa L.) in Virginia tobacco (Nicotiana tobacum L.). Beitrage zur Tabakforschung International. 20 (2): 77-81.

[36].Das, M.N. and Giri, N.C. (1986). In: Design and analysis of experiments (2nd Edition). Wiley Eastern Ltd. New Delhi pp. 448.

[37].Das, T.K. (1999). Is transformation of weed data always necessary. Ann. Agric Res. 20 (3): 335-341.

[38].Dhanapal, G.N. (1996). Management of broomrape (Orobanche cernua) in tobacco (Nicotiana tabacum). Management of broomrape Orobanche cernua in tobacco Nicotiana tabacum. 183 p.

[39].Dhanapal, G.N., Struik, P.C., Timmermans, J.M. and Ter Borg, S.J. (1998a). Post emergence control of broomrape with natural plant oils. J. Sustainable Agriculture. 11 (4): 5-12.

[40].Dhanapal, G.N., Ter, Borg, S.J. and Struik, P.C. (1998b). Post-emergence chemical control of nodding broomrape (Orobanche cernua) in bidi tobacco (Nicotiana tabacum) in India. Weed Tech. 12 (4): 652-659.

[41].Fisher, R.A. (1958). Statistical Methods for Research Workers. Oliver and Boyd., Edinburgh.

[42].Gardner F.P., Peace R.B. and Mitchell R.L. (1988). Physiology of crop plants. Scientific publishers, Jodhpur, India.

[43].Gill, G.S. and Kumar, Vijay (1969). 'Weed index' as new method for reporting weed trials. Indian J. Agron. 14 (1): 96-98.

[44].Kaneria, B.B. and Patel, Z.G. (1995). Effect of weed management practices and nitrogen on the growth, yield and nitrogen uptake by mustard (Brassica juncea L.). Gujarat Agric. Univ. Res. J. 21 (1): 1-5.

[45].Kataria, O.P., Chauhan, D.R. and Balyan, R.S. (2003). Effect of herbicides on weeds and seed yield of tobacco (Nicotiana tobacum L.). Indian J. Weed Sci. 35 (1/2): 151-152.

[46].Krishnamurthy, G.V.G. and Chari, M.S. (1991). Further studies on post-emergence control of broomrape on tobacco with plant oils. In: Proceedings of the 5th International symposium of parasitic weeds, Nairobi, Kenya, 24-30 June 1991. pp. 108-110

[47].Kumar, S. (2002). Preliminary studies on the control of broomrape in mustard. Indian J. Weed Sci. 34 (3 \& 4): 303-304. 


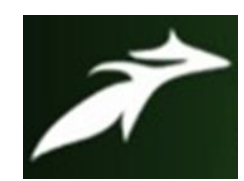

Ramakant Singh Sidar, International Journal of Advances in Agricultural Science and Technology,

Vol.4 Issue.2, February- 2017, pg. 19-32

ISSN: 2348-1358

Impact Factor: 6.057

[48].Kurchania, S.P., Rathi, G.S. Bhalla, C.S. and Mathew, R. (2002). Direct and residual effects of herbicides for weed control in soybean-mustard cropping system. JNKVV Research Journal. 36(1/2): 13-16.

[49].Meena, M. L. and Dinesh Sah (2011). Effect of weed control and fertilization on yield attributes and seed yield of mustard (Brassic juncea L.) under western plains of UP. Environment and Ecology;. 29: (2A), 929-931.

[50].Mishra, J.S. and Kurchania, S.P. (2001) Weed dynamics, nutrient uptake and yield in Indian mustard (Brassica juncea)-weed ecosystem as influenced by nitrogen levels, planting geometry and herbicides. Indian J. Weed Sci. 46(2): 296-303.

[51].Mishra, P.J. and Sharma, S.N. (2001). Weed dynamics and dry matter production in mustard as influenced by fertility levels and weed management practices. Indian J. Weed Sci. 33(3/4): 151-155.

[52].Muhur, R.N., Datta, N.P., Sankar, Subramoney, H. Leley, V.K. and L. Vay, Donaline (1965). Soil testing in India. U.S. Agency for International Development Mission to India pp 39, 40, 45.

[53].Nemli, Y., Emiroglu, U. and Kucukozden, R. (1989). Chemical control of broomrape (Orobanche ramosa L.) in tobacco. In: Progress in Orobanche research Proceedings of the international workshop on Orobanche research, Obermarchtal, Germany, 19-22 August 1989. pp. 191-199.

[54].Nepalia, V. (2005). Influence of weed control and sulphur on growth, yield and economics of mustard production. Research on Crops. 6(1): 35-38.

[55].Olsen, S.R., Cole, C.V., Watanabe, F.S. and Dean, L.P. (1954). Estimation of available phosphorus in soils by extraction with sodium bicarbonate. USDA Circular, 937.

[56].Om Prakash (2002). Weed management in Indian mustard (Brassica juncea) on terraced ravine alluvial soils. Annals Agric. Res. 23(2): 280-283.

[57].Palled, Y.B. (1979). Studies on weed control in irrigated bidi tobacco with special reference to Orobanche using herbicides and trap crops. In: M.Sc. (Ag.) thesis submitted to UAS, Bangalore, India.

[58].Palled, Y.B., Patil, Y.S., Panchal, Y.C. and Hosmani, M.M. (1985). Studies on chemical weed control in irrigation bidi tobacco with special reference to Orobanche. Indian J. Weed Sci. 17 (1): 6-11.

[59].Piper, C.S. (1950). Soil and Plant analysis. Hassel Press, Adelaide (Australia).

[60].Power, M.S., Jadhav, M.G., Mane, M.J. and Chavan, S.A. (2003). Response of mustard (Brassica juncea (L.) Czernj \& Cosson) to weed control and soil test based fertilizer application. Indian J. Dryland Agric. Res. Dev. 18(2): 157-161.

[61].Prusty, J.C., Behera, B. and Mohanty, S.K. (1996). Herbicidal control of weeds in Indian mustard (Brassica juncea). Indian J. Agron. 41 (2): 339-340.

[62].Rana, D.S. (2006). Effect of planting patterns and weed management on weed suppression, productivity and economics of African mustard (Brassica carinata) and Indian mustard (Brassica juncea) intercropping. Indian Journal of Agricultural Sciences; 76: (2), 98-102.

[63].Rao, G.N. (1983). In: Statistics for Agriculture Sciences. Oxford and IBH Publishing Co. New Delhi pp. 376. 


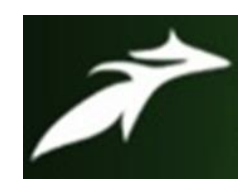

Ramakant Singh Sidar, International Journal of Advances in Agricultural Science and Technology,

Vol.4 Issue.2, February- 2017, pg. 19-32

ISSN: 2348-1358

Impact Factor: 6.057

[64].Rathi, J.P.S., Yadav, Y.S., Verma, S.K. and Tiwari, A.N. (2005). Integrated weed management in irrigated mustard (Brassica juncea L.). Plant Arch. 5 (1): 179-183.

[65].Richard, L.A.E. (1954). Diagnosis and improvement of saline and alkaline soil. U.S.D.A. Washington. Hand book No. 50.

[66].Sadasivam, S. and Manikam, A. (1992). Biochemical method for agriculture science, Willey Eastern, New Delhi.

[67].Sandri, G., Sandri, A. and Martini, G. (1998). Protection of tobacco against orobanche. Informatore Agrario. 54 (26): 74-75.

[68].Singh, R. K. Singh, R. P. and Dhiman Mukherjee(2009). Effect of fertilizer placement and weed management practice on weed dynamics and yield of rainfed mustard (Brassica juncea L.). Environment and Ecology. 27: (4B), 1932-1938.

[69].Singh, Thakar (2009). Efficacy of different herbicides for weed control in Indian mustard. Crop Res. 38 (1,2 \& 3): 33-34.

[70].Sinha, K.K., Bharati, V., Singh, S.J. and Chaudhary, B.P. (2005). Effect of nitrogen, crop geometry and weed management system in Indian mustard. J. Res. Birsa Agricultural University 17(1): 15-18.

[71].Subbaih, B.V. and Asija, G.L. (1956). A rapid procedure for the estimation of available nitrogen in soils. Curr. Sci. 5: 259-268.

[72].Tekale, K.U., Khanpara, V.D., Deshmukh, M.S. and Bonde, A.M. (2005). Effect of weed management practices on growth and yield contributing parameters of Indian mustard and their correlation with yield J. Soils and Crops. 15 (1): 183-186.

[73]. Tiwari (1998). Weeds are regarded as one of the major negative factor of crop produce loss due to competitions for nutrients, moisture, light and space which have been reported as high as 30-70\%. Indian j. weed sci. 30: 149-152.

[74]. Tiwari, J.P. and Kurchania, S.P. (1993). Chemical control of weeds in Indian mustard. Indian J. Agril. Sci. 63(5): 272-275.

[75].Watson DJ. (1947). Comparative physiological studies on the growth of field crops. Annals of Botany 11: 41-76.

[76]. Yadav, R.P. (2004). Effect of herbicides alone and in combination with cultural methods on weed control in Indian mustard (Brassica juncea). Indian J. Weed Sci. 49(4): 268-270.

[77].Yadav, R.P., Shrivastava, U.K. and Dwivedi, S.C. (1999a). Comparative efficiency of herbicides in controlling Ashphodelus tenuifolius and other weeds in Indian mustard (Brassica juncea). Indian J. Agron. 44 (1): 151-155.

[78]. Yadav, R.P., Shrivastava, U.K. and Dwivedi, S.C. (1999b). Weed control in Indian mustard (Brassica juncea). Indian J. Agron. 44 (3): 613-616.

[79].Yadav, R.S. and Poonia, B.L. (2005). Effect of crop and herbicide rotations on weed dynamics, with special reference to Asphodelus tenuifolius in mustard in arid region of Rajasthan. Indian J. Weed Sci. 37(1/2): 68-73. 